\title{
Negotiating Liminal Identities in Mohja Kahf's The Girl in the Tangerine Scarf
}

\author{
Susan Taha Alkarawi (Corresponding author) \\ Department of English \\ Faculty of Modern Languages and Communication \\ Universiti Putra Malaysia (UPM) \\ 43400 Serdang, Selangor, Malaysia \\ Tel: $+60(0) 18-2514473$ \\ E-mail: susanyousef2000@yahoo.com, \\ Ida Baizura Bahar \\ Department of English \\ Faculty of Modern Languages and Communication \\ Universiti Putra Malaysia (UPM) \\ 43400 Serdang, Selangor, Malaysia \\ Tel +60 (03)-89468773＜wide>E-mail: ida@fbmk.upm.edu.my
}

Received: 21-10- 2012

Accepted: 06-01- 2013

Published: 01-03- 2013

doi:10.7575/aiac.ijalel.v.2n.2p.101

URL: http://dx.doi.org/10.7575/aiac.ijalel.v.2n.2p.101

\begin{abstract}
This paper challenges the thought that the term 'Muslim woman' connotes submissive or backward and is in need of rescue by the West through a literary analysis of the work by Mohja Kahf (b.1967), a leading contemporary ArabAmerican Muslim woman writer. In her novel, The Girl in the Tangerine Scarf (2006), Kahf focuses on the oppressive and discriminatory practices Muslim women encounter when wearing the hijab or veil where the main character and narrator experiences a type of identity split, or fragmentation, when assimilating into mainstream American culture. As a tool for analysis, the notion of liminality by Victor Turner (1920-1983), a British cultural anthropologist, is used to analyze the narrator's choice of being 'betwixt and between' the state of things, or being 'neither here nor there'. The resolution of social and personal conflicts portrayed is mapped to the stages of liminality.
\end{abstract}

Keywords: Veil, Liminality, Identity, Muslim Woman, Assimilation, Discrimination, Conflicts, Tradition

1. Introduction

This paper aims to examine the novel The Girl in the Tangerine Scarf (2006) by Mohja Kahf (b. 1967). The novel is a work of fiction which relates to the writer's own experiences of being an Arab Muslim woman living in the United States of America (henceforth referred to as U.S.A or America). Many of the scenes of racism and violence in the novel seem to be drawn from Kahf's own childhood experiences in America and specifically in Indiana. It is not surprising then that Kahf's great suffering of bigotry and racism impressed upon her an enduring legacy that eventually helped her to better frame her adult self. This fact is indeed underscored by the book cover featuring a woman wearing a tangerine scarf which coincidentally happens to be the portrait of the author herself. Kahf's novel in some way explores the struggle of the experiences of immigrants, Arabs and Muslims, in the context of an American or Western society that generally misreads such identities. Throughout the novel, Kahf focuses on varying aspects of the hijab (henceforth referred to as the veil) whose role is underlined in the Qur'an in the twenty-forth chapter, Surah An-Nur:

And tell the believing women to lower their gaze and be modest, and to display of their adornment only that which is apparent, and to draw their veils over their bosoms, and not to reveal their adornment save to their own husbands or fathers or husbands' fathers, or their sons or their husbands' sons, or their brothers or their brothers' sons or sisters' sons, or their women, or their slaves, or male attendants who lack vigour, or children who know naught of women's nakedness. And let them not stamp their feet so as to reveal what they hide of their adornment. And turn unto Allah together, O believers, in order that ye may succeed. (p. 31)

In an effort to dismantle the misconstrued images Westerners have of Muslim women who wear them, it is believed that Kahf executed this with the main objective of changing the hegemonic as well as patriarchal discourse regarding the veil, especially since this particular image has become a key indicator of Islam and also the focus of Islamic treatise post-9/11.

Here, we focus on the liminal experience and conflict of Kahf's protagonist, a Syrian immigrant named Khadra Shamy, who is caught between her American identity and her Muslim and Arab identity. In the narrative, Khadra fluctuates between retaining her cultural differences and assimilating with the American culture, or simply choosing to adhere to her Muslim culture. The arguments are analysed based on Victor Turner's concept of liminality as framed in his theory on the rites of passage where we attempt to reveal how identities and struggles are developed and are carried out through the image of the veil. In our analysis of Kahf's novel, we address apparent rites of passage which consist of 
three general stages: a separation stage (the ritual individual is separated in some way from his or her former life), a liminal stage (the boundary or margin between two states, where one experiences an ambiguous positions "betwixt and between" the former and future place in life), and a stage of reincorporation (in which the subject rejoins society in their new state in life). It is not presupposed, however, that these aspects of the process will necessarily be clearly differentiated or will follow one another in perfect order.

\section{Text and Context}

The author was born in 1967 in Damascus, Syria but, in 1971, just before she turned four, her family migrated to America so that her father could pursue a graduate degree and her mother could finish a B. S. in pharmacy. Kahf received her B. A. at Rutgers University; where she studied Comparative Literature and Political Science and then went on to complete her Ph. D. in Comparative Literature from Rutgers in 1988. Kahf is currently associate professor of Comparative Literature at the University of Arkansas. As she grew up in America, she became aware of anti-Muslim sentiments and ignorance in America where, after the family moved to Plainville, Indiana, Kahf experienced a great deal of bigotry and oppression.

Kahf writes of cultural disparities encountered by Muslims in America, focusing on Muslim to non-Muslim conflict as well as Muslim to Muslim associations and the contentions amongst them. Her viewpoint disputes hegemonic imageries of Arab-Americans, Muslim women in particular, reviewing mainstream representations of the culture. America has such a diverse population of peoples, all who migrated to America either willingly or by force (as in African slaves), and these immigrants arrived in a land already populated by a diverse native population, which they proceeded to eradicate. For this reason, Kahf is very aware that America is embattled in bitter racial issues, and does not have a good track record in this regard. After 9/11, Kahf is very aware that an already divisive nation regarding race became more so. Skin color, ethnicity, manner of dress, and religion contributed to the 'Arab' becoming a focus of the country's inherent racism.

In The Girl in the Tangerine Scarf, Kahf chronicles important events that occurred after the 9/11 attacks in America as these events have been proven to have affected the lives of Arab-Americans profoundly. The novel is about an ArabAmerican female's journey in search of identity where, through the protagonist's journey into herself and the Middle East, Khadra attempts coming to terms with her Arab and Islam identities as well as her American identity. Khadra however does give up wearing the veil by the novel's end yet embraces a new persona emerging from the deep strife she underwent throughout her childhood and early adult life.

In her novel, Kahf undermines the subversive depiction of Muslim women common in America where it is essentially about Muslims and women's identity in particular. The novel's cover photo, of a woman wearing a tangerine scarf, bolsters her theme regarding the veil; to Westerners, it is a symbol of oppression. It is widely acknowledged that Muslim women are usually denied from wearing clothes with bright colors in certain conservative societies. Yet, at the same time, the Muslim woman on Kahf's cover also wears a black T-shirt and blue jeans which means that Kahf is transmitting many implicit messages about Muslim women regarding Islam and the West. These messages speak of multiple social identities, not a singular and stereotyped identity, for Muslim Arab-American women in the U.S.A.

\section{Constructing New Identities Across New Communities}

Kahf's novel reflects the struggle of persecution and victimization of veiled women in America and Muslim countries in order to highlight the type of oppression and discrimination Muslim women experience worldwide. In doing this, she creates a new genre of the practicing Muslim woman who is thought to be oppressed by the veil only to prove that the image of the veil has been created and manipulated to be used as a tool to oppress her instead. This is achieved through the negative meaning attached to it in America post-9/11 as well as in the patriarchy society of Muslim countries. In relation to the novel, Turner's liminality as it is found in rites of passage provides a conceptual framework through an understanding of how heroines must negotiate their own fates. The quality of a rite of passage which most interested Turner was the liminality particularly associated with the middle, transitional phase. Turner (1967) argues that "liminality includes few or none of the attributes of the previous or future states, and that the features of liminality are ambiguous; that is, they are outside of all society's standard classification (P. 94). During the liminal movement between states, the individual finds themselves "betwixt and between" positions normally assigned by law, custom, convention, and ceremony, where they experience a suspension or reversal of the normal rules of living (Turner, 1969, pp. 94-95).

Often the liminal separation from former and future ways of life is reflected in a physical removal from the familiar places and people of their former life, and in a sense of being outside of the ordinary flow of time (Turner, 1979, p. 399). In this experience of temporary separation, Turner argues that the liminal characters are ambiguous. This ambiguity can be conveyed through the use of symbols; thus, it is important to study "symbols and social action, and praxis" symbols, with their multi-vocal reference which can "feed back into the central economic and political-legal domains and arenas, supplying them with goals, aspirations, incentives, structural models and raison d etre' (Turner, 1974, p. 64). Here, we argue that such a symbol can be and is the veil. Khadra, the protagonist in the novel, is an Arab Muslim woman residing in the United States. She experiences subjugation as a result of the image of the veil as backward; therefore, it must be shed. She is exposed to the hardship and conflict Muslim women suffer; hence, this gives her the will to discover her authentic self and realise her commitments to herself, her family, and her subculture. In the novel, Kahf discusses the issue of the Muslim woman's invisibility and liminality, especially if she takes on the Muslim veil that is viewed in the West as a fetish sign of oppression in the eyes of hegemonic discourse. In Khadra's liminal journey in the search for a coherent identity, she is faced with many obstacles that compel her to make a decision about who she is and what stance she could take. Throughout her journey, Kahf exposes Khadra to a wide range of options, styles of lives and Muslim individuals that help her in the formation of herself and the development of 
the identity she chooses for herself. Khadra meets a variety of practising and secular Muslims, empowered and traditional Muslim men and women who all add to her experience and knowledge of what Islam is all about.

3.1 Rites of Passage: Separations

In the novel, one of the childhood experiences in America that Khadra continues to recall in her adult life was when she was harassed at school and mocked because of the veil. One of the children at school takes from Khadra her Malcolm X book and then tells her if she takes off "her "towel," he would return it to her. She does not and, though she tries to resist, the children hold her down until they rip her scarf. Her antagonist comments, "Look, raghead's got hair under that piece a shit" (Kahf, 2006, p. 124). Khadra shouts at them "I hate you" and one of them shouts back at her telling her "It's just hair, you psycho" (p. 124).

In addition, Khadra experiences physical separation from people in America who are seemingly more like her than the children who taunted her as a child. Bitsy, Khadra's Muslim Iranian-American college roommate, worry when she sees Khadra wearing her veil and asks her "You're not one of those fanatics, are you?" to which Khadra replies: "Of course I am ... I come from a long, proud line of fanatics" (p. 363). Indeed, her roommate is an example of a Muslim, though originally from a predominately Muslim nation, in fact looks on Islam and Muslims negatively and views its followers as fanatics and terrorists. Khadra's response comes from her awareness that the term 'Muslim' has now become synonymous with fanaticism or fundamentalism and so does not mind being called fanatic since practising the Islamic religion is perceived as fanatic so she is logically a fanatic in this sense. She is not offended by Bitsy's ignorance of the religion or misconceptions of it as she realizes Bitsy is one of the people she will encounter all her life. Nonetheless, she is prevented from greater closeness with Bitsy, an Iranian American woman, because of the veil and for being a practising Muslim.

3.2 Rites of passage: Liminality and 'betwixt and between'

As we have seen thus far, Khadra has had a conflicted identity; she has tried to find peace between her multiple social identities. She has strived to reconcile her identity as an American female with her Islamness and Arabness. In the novel, Khadra struggles throughout the narrative trying to understand what it means to be a Muslim, an American, an Arab and a woman simultaneously. Part of Khadra's journey is to find a way to connect the varying characters she encounters and their treatment of the veil. At the beginning of her journey, Khadra is of the opinion that becoming an American citizen means betraying her Arab and Muslim identity and that it would turn her into another person she would not approve. When eventually her family obtains the American citizenship, she is forced to deal with her new identity. Here, the narrator reveals the conflicted emotions Khadra experiences as she obtains her American citizenship: To her, taking citizenship felt like giving up, giving in. After all she'd been through at school, defending her identity against the jeering kids who vaunted America's superiority as the clincher put-down to everything she said, everything she was. Wasn't she supposed to be "an Islamic warrior woman, a Nusayba, a Sumaya, An Um Salamah in exile, by the waters dark, of Babylon?" (p. 141).

Kahf portrays Khadra as fascinated with the concept of empowered Muslim women and her fascination with these legendary "women warriors" leads her to think that, if she becomes an American citizen, she can no longer follow their good example. Also, Khadra initially equates Islam with foreignness; she is unable to comprehend the mixture that makes Muslim Americanism, challenging perceptions of their incompatibility or contradictoriness. This is clear in a sermon by her father, Wajdy, soon after she obtains her American citizenship. Khadra's father tries to reconcile the two identities within him and within other American Muslims as illustrated in this speech at the mosque:

In many ways...America is more Islamic than the countries of the Muslim world. There is no widespread corruption. You can enter a judge's offices and not need to bribe his secretary for the simple basic services...do not...think that we will stop protesting against the immoral and unfair policies of America outside, in the Muslim world. ... But let's face it: here inside America, there are many good qualities. Law and order, cleanliness, democracy, freedom to work...freedom to practice religion. These are Islamic qualities. America...is like Islam without Muslims. And our sick and corrupt Muslim home countries-they are Muslims without Islam. (pp. 143-144)

Apart from that, Khadra is exposed to diverse Muslim countries in the Middle East and in America in her search for an autonomous identity. She tries to learn more about herself and the different paths she can take as a Muslim American. During her trip to her home country, Syria, she finds herself caught between religion and culture. Khadra does not desire to lose either one; she chooses a path that allows for her to adjust her identity as well as the components that will form her ultimate 'self'. In fact, Khadra's journey with the veil ends in Syria where she decides to take off her veil and practise Islam through other manifestations. She tries to come to terms with herself and her views of religion:

The covered and the uncovered, each mode of being had its moment. She embraced them both. Going out without hijab meant she would have to manifest the quality of modesty in her behavior, she realizes one day, with a jolt. It's in how I act, how I move, what I choose, every minute. She had to do it on her own now, without the jump-start that a jilbab [long garb] offered. This was a rigorous challenge. Some days she just wanted her old friend hijab standing sentry by her side. (p. 312)

After she travels to Saudi Arabia, Khadra and her cousin's subsequent behaviour also ruptures the boundaries between veiled and unveiled Muslim women and destabilises a dichotomy between veiled and unveiled, assumed to be fixed. In Saudi Arabia, Afaaf, Khadra's cousin, takes her out to meet her male friends. She introduces Khadra to them as her "American" cousin, which is read as liberated and sexually available although she does not take off her veil. One of the men points at Khadra's veil and says to her, "Surely you don't wear that thing in America" (p. 178). A few minutes afterwards, he pulls her veil down and "pushes his other hand up against her breast and his mouth was grazing her now 
exposed neck" and, as she tries to get him off of her, he asks her, "What is it-what is the big deal-we're not doing anything you have to worry about ... don't tell me you never do stuff like this in America" (p. 178).

What we can argue here is that, through her decision not to wear the veil, Khadra seems to be giving herself some relief from being judged by a piece of cloth. Shedding the veil definitely improves her chance to be more American and less Muslim, not in her own eyes, but in the eyes of others. Although the veil has been part of her identity, the meanings it takes on has not thus far described her or reflected who she really is. Hence, Khadra's dilemma can be summed up through an articulate statement by Abdurraqib (2006) on women's narratives that focus on religion:

Islam becomes the religion of the other and the culture from which women need to be liberated. In these narratives, women are held accountable for both religious and cultural traditions of the old country. ... But when Islam is conflated with cultural practices and is seen as oppressive, the female protagonists must consider compromising both religion and culture to incorporate themselves into American society. (p. 56)

In addition to that dilemma, going overseas is what has enabled Khadra to also see that she is irrevocably American, in some ways she could not pin down. She visits Syria to 'find' herself, believing that a spiritual discovery of her cultural origins will help her further understand what to do regarding her own identity, without external pressure. There, she comes to learn about her mother's suffering from Teta, her grandmother, who reveals some truths Khadra has been unaware of. It transpires that, after the death of her mother, Ebtehaj. Ebtehaj's stepmother, who was secular, gave her mother a hard time because of the veil where she was mocked her for wearing it. This is because during those times, according to Teta, "The city was against it, the tide was against it" (p. 275). Teta narrates "she tried everything-she'd yank it right off her head. I heard she put it in the pot and shat on it" (p. 275) and she was embarrassed to be seen in public with her veiled stepdaughter; she even made Ebtehaj walk on the other side of the street. Ebtehaj's stepmother did not allow her to continue with her Quran circle that she became interested in after her mother's death and tried to force her into a marriage with a man "who drank and whored, just to make her misery lifelong" (p. 276). Through these stories about her mother's past, Khadra bonds with her grandmother and comes to a better appreciation of her mother. She realizes that her mother was strong enough to hold on to the veil that had caused her so much agony and was determined to follow her Islamic beliefs no matter what the trend was at the time. The struggles she has learnt foster in her a sense that she is not, in fact, alone in her experiences of separation and feeling 'betwixt and between'.

Kahf's Syria is also used to exemplify how women were persecuted because they chose to wear the veil. Khadra hears her aunt tell of events in Syria in 1982 where, during this period, the Islamic front rebelled against the Syrian government that was repressive, corrupt, and dictatorial (Cleveland, 2004, p. 362).They seized control of parts of the city of Hama and the government in response launched "a deadly campaign" against the city and its civilians. At least 10,000 people were killed by the armed forces and a warning was issued by the government to potential dissidents that the regime would use all the force at its disposal to remain in power. Apparently, the government after that had become anti-religious because its supremacy had been under threat by the Islamic front. Khadra's aunt explains that, in 1982, the capital was blocked by the government and a thousand paratroopers got hold of any woman who was wearing the veil. Her aunt states, "You could strip off your hijab [veil]..., or get a gun to your head" (p. 281). She adds that her daughter, Reem, on her way home, got stopped by the paratroops so she took off the scarf right away where her aunt comments "Why endanger your life for it?" ( p. 281) The paratroops asked her to take off her clothes because she was fully covered with her long garb, but did not wait for Reem to take off her clothes so she ripped it off her and "holds it up in the air and sets it on fire with a blowtorch" (p. 281). Her uncle Mazen explains to her that that had happened because of dissidents like Khadra's mother and father who, in his opinion, had politicised the veil and upset the government which then led to this behaviour. Hearing the story of her mother shocks Khadra into realising how momentous her parents' decision to leave their home and migrate to America; she also comes to realize why her mother sticks to wearing the veil.

Because of what her mother suffered in a Muslim country, Khadra comes to appreciate the freedom she enjoys in America where she is able to practise her religion without persecution. She may have to deal with the reality of stereotypes and misconceptions; nevertheless, her situation as a practising Muslim in America is better than others in the so-called Muslim countries. However, in America, Khadra and her mother are faced with other form of challenges: narratives and scenes of immigration and identity imposed by the hegemonic culture that requires them to hold on to a single allegiance and to let go of any other. Their dilemma lies in the fact that they are to make a decision with regards to their identity, and they are limited by the two options made available by the dominant culture: either to express their Muslim identity through the veil or assimilate with the American culture.

Indeed, Kahf's work deals with these challenges and chronicles the reality faced by Muslim women in their efforts to assimilate with the host culture while preserving their own culture. In the novel, Khadra also needs to determine whether she should continue to wear the veil or remove it in order to be accepted within the American society. Because Muslim women experience many pressures from their parents, their culture and their society at large, Kahf builds her story revolving around these pressures and by portraying her protagonist on a spiritual journey of challenges in facing everyday reality. This pressure to preserve the original culture and system of beliefs can be illustrated by what Khadra is told by her mother and aunt. Khadra's mother, Ebtehaj, admits to her daughter that "Our biggest fear was always losing you...Losing our children to America. Having you not keep Islam one hundred percent." (pp. 383-384). Later on in the narrative, her aunt reiterates the same concern:

We put a lot of weight on your shoulder. ...Not just you-all our children . ...But especially you girls. You had a lot to measure up to. ...Young in a strange land; your mother was, like me. ...Afraid...of being swallowed up by this land, reduced to nothing. ...And we were so idealistic. ...But we put it all on you. ... Wanting you to carry our vision for us, our identity, our entire, on your heads." (pp. 404-405) 
As we can see here, by shifting locations, the author explores the protagonist's internal conflict as Khadra meets different Muslim characters and experiences Islam in different locations. This technique enables Khadra to observe the way veiling 'plays out' in different social and geopolitical localities.

\subsection{Rites of passage: Reintegration}

Once she returns to America, Khadra finally realises that she is American and cries out for the first time "Homeland America" (p. 313). Here, the narrator describes Khadra's reconciliation with her newly attained American identity:

And here she is. Eighteen years distant from that ten-year-old girl terrorized by neighborhood boys shouting 'Foreigners go home!' and the girl bewildered by her mother's sobs of 'We are not American!' as she scrubbed her clean of American dirt, eleven years away from the girl who cried into her pillow in defeat the day the U.S. citizenship papers came, caught between homesick parents and a land that didn't want her. Not just didn't want her, but actively hated her, spit her out, made her defiant in her difference, yet at the same time made her unfit to live anywhere else. ( $p$. 313)

As recalled, Khadra is constantly met with various images of Muslim women that represent the heterogeneity within the Muslim community often left out from media representations and the hegemonic discourse. Initially, we are presented with the image of an educated and ambitious woman who wanted to go to medical school. Khadra's mother explains to her daughter that she thought she would go to medical school, "But after [she] graduated, [she] chose to stay home. "For the children" (p. 21). Khadra's mother had sacrificed her interest in furthering her education in order to care for her children, "I used to dream I would be a doctor one day, and open a free clinic for poor people" (p. 26). Another image of an empowered woman is Khadra's grandmother, Teta, who was a telephone operator long ago and was among "the very first wave of working women" (p. 271) as it was one of the new jobs that had opened up for women in the old days. Her grandmother did not conform to a society that decided that "a telephone girl's job was a bad thing, a thing for loozies." Teta insists on saying "We wanted to be the New Woman" (p. 271).

Khadra's friend, Maryam, is another image of an independent Muslim woman whom Khadra respects and learns from as she reintegrates with those around her whom she had not previously appreciated. Maryam does not always go to the mosque or belong to a certain one but practises her religion on her own. The narrator gives us a glimpse of how Khadra perceives this new image of a Muslim woman in America:

This friend mapped Muslim space in a way new to Khadra. Maryam's thing was service. Service to the poor is service to God. ... I don't have to be working only with Muslims or on Muslim issues or Muslim this or Muslim that. By representing impoverished defendants, I'm manifesting Muslim values in my life. We don't need a ghetto mentality. ( $p$. 367)

Here, Maryam represents a positive image of the practising Muslim American woman who is able to reconcile her Muslim values with her American life. She is successful in her professional and personal life as well where she concentrates on the core values of uncontaminated Islam that urges a Muslim to manifest their faith in their conduct and everyday life. She does not conform to the female role assigned by the patriarchal system nor can anyone tell her how to lead her life.

In the novel, Kahf gives Khadra this example of a Muslim woman who created a new identity for herself without compromising her identity so as to be accepted by mainstream America. By using this model, Kahf spotlights the conflict between the secular and the practising Muslims and how they view each other. To Americans, Muslims are often reduced to a single image of brainwashed followers of Islam or terrorists. Eventually, Khadra is not stymied by a single image of Islam; she has many examples to choose from and emulate as she lives the life she wants. Bisty, Khadra's Iranian roommate, for instance, is a secular Muslim who contributes to the stereotypes of Muslims. She herself does not identify herself as a Muslim Iranian where, once she moved to America and obtained her citizenship, she changed her Muslim name Fatima-Zahra to Bisty. Indeed, Khadra is puzzled by the fact that she refuses to tell her what her Iranian name was. When Khadra asks her why she changed her name, Bitsy tells her, "So we could do things like...order pizza without the guy on the phone getting all confused. ...And job applications and such,...Makes things just a whole lot easier" (p. 369). Bitsy chooses not to be associated with Muslims or Iran and, since she carries no visible markers that give away her identity, she is able to lead an ordinary life without experiencing discrimination against her religion. Thus we can see here that, through the various female characters of Khadra, Ebtehaj, Teta, Maryam and Bitsy, Kahf constructs heterogeneous identities, and hence deconstructs the homogenised image of Muslim and Arab-American women.

Khadra's story concludes with a tentative understanding of her different selves where she is able to provisionally reconcile herself as an Arab, a Muslim, and an American. However, her indecision towards wearing the veil does not resolve itself completely. Khadra's journey between countries and her experiences with the veil end with her redefining her relationship with the veil in which she decides not to wear the veil at all times. She still practises Islam and shows modesty through her behaviour instead of through wearing the veil. Undeniably, Khadra is not ashamed of the veil nor does she gives up on it in favour of Western fashion but chooses to wear it occasionally. In fact, she refuses to give up on it entirely and makes it a point to wear it whenever she wants to assert her Muslim and Middle Eastern identity. The narrator illustrates how a redefined Khadra deals with the veil after her experiences:

People stare. She is still in hijab. She pulls the tangerine silk tighter around her head. The stares only ever make her want to pull it on tighter, not take it off the way Seemi keeps suggesting she do after every Middle Eastern crisis dredges up more American hate. ... It's my connector, Khadra has tried to explain to Seemi once about wearing the scarf through hard times. It makes me feel connected to the people of my family, my mosque, where I come from. My heritage... "Don't be ridiculous", Seemi said. Take the damn thing off; it's not worth risking your life for." (p. 424) 
At the end of the novel, she decides to reclaim her cultural heritage and publically display her connection to her Middle Eastern and Muslim origin whenever she needs to and at whatever occasion that deems it appropriate.

\section{Conclusion}

Through the analysis, we can conclude that Khadra is an enlightened woman who wears the veil because she believes in what it represents. She decides to wear the veil in Muslim countries as well as America in spite of the difficulties she encounters while wearing it. She refuses to accommodate herself to society's mores and rejects patriarchal oppression in countries that do not give Muslim women the option to practise freedom of choice. In America, she does not acquiesce to negative imageries of the veiled Muslim woman and knows that she would be respected more if she did not wear the veil because, ironically, it is a condemned sign that represents a despised difference. Through the novel, Kahf has created a new voice for the veiled woman and a new outlook for Muslim-American women. She explores all aspects of Khadra's along with other Muslim women's lives to counteract a one dimensional image of the Muslim ArabAmerican woman as 'less than' and powerless. Through her narrative, Kahf reflects the heterogeneity within the Muslim and Arab-American community and their negotiation of different patriarchal contexts. Kahf focuses on Khadra's journey in search of herself and identity and, through her and her female relations, she represents the reality surrounding heterogeneity in Muslim women's roles and attitudes. She also presents the various challenges that limit these women's lives whether they are due to race, religion, and the veil or patriarchy and gender oppression.

\section{References}

Abdurraqib, S. (2006). Hijab scenes: Muslim women, Migration, and Hijab in Immigrant Muslim Literature. MELUS, 31, P.55-70.

Cleveland, W. L. (2004). A History of the Modern Middle East. ( $3^{\text {rd }}$ ed $)$. Boulder: Western Press.

Kahf, M. (2006). The Girl in the Tangerine Scarf. New York, NY: Carrol \& Graf Publishers.

Turner, V. W. (1967). Forest of Symbols: Aspects of Ndembu ritual. Ithaca, N.Y: Cornell University Press.

Turner, V. W. (1969). The Ritual Process. Chicago: Aldine.

Turner, V. W. (1974). Metaphors of Anti-structure in Religious Culture. In V. Turner(Ed.), Changing Perspective In the Scientific Study of Religion. New York, NY: John Wiley and Sons. (pp. 63-84). 